\title{
6. SITE 517: WEST FLANK, RIO GRANDE RISE ${ }^{1}$
}

\author{
Shipboard Scientific Party ${ }^{2}$
}

\section{HOLE 517}

Date occupied: 30 March 1980

Date departed: 31 March 1980

Time on hole: $27.2 \mathrm{hr}$.

Position: $30^{\circ} 56.81^{\prime} \mathrm{S}, 38^{\circ} 02.47^{\prime} \mathrm{W}$

Water depth (sea level; corrected m, echo-sounding): 2963

Water depth (rig floor; corrected m, echo-sounding): 2973

Bottom felt (m, drill pipe): 2970.4

Penetration (m): 50.9

Number of cores: 12

Total length of cored section (m): 50.9

Total core recovered $(\mathrm{m}): 48.49$

Core recovery $(\%): 95$

Oldest sediment cored:

Depth sub-bottom (m): 48.4

Nature: Calcareous ooze

Age: Pliocene (3.1 Ma)

Measured velocity $(\mathrm{km} / \mathrm{s}): 1.5$

Principal results: Site 517 represents a relatively complete late Pliocene and Pleistocene record of the history of North Atlantic Deep Water (NADW) production. The upper $51 \mathrm{~m}$ of sediment was continuously cored by hydraulic piston corer (HPC) with high core recovery $(95 \%)$, and the sediment recovered represents a complete stratigraphic record back to the middle Pliocene (approximately 3.1 Ma). Bad weather forced abandonment of the site before its Miocene objective was reached. Nevertheless, Site 517 recovered a detailed history of the oxygen isotopic record for the past $3.1 \mathrm{~m} . \mathrm{y}$., a record that may be pertinent to understanding the growth history of the northern hemisphere ice sheet and its effects on NADW production.

Several key geologic indices at Site 517 are interpreted as indicators of rates of NADW production. These include: (1) planktonic foraminiferal dissolution indices, (2) benthic foraminiferal assemblages, (3) carbon isotopic composition of benthic foraminifers, and (4) trace element geochemistry of benthic foraminifers. Some of these indices were analyzed for this Initial Reports volume, and some techniques are still being developed. Our preliminary conclusions include the following:

\footnotetext{
${ }^{1}$ Barker, P. F., Carlson, R. L., Johnson, D. A., et al., Init. Repts. DSDP, 72 : Washington (U.S. Govt. Printing Office).

2 Peter F. Barker (Co-Chief Scientist), Department of Geological Sciences, University of Birmingham, Birmingham, United Kingdom; Richard L. Carlson (Co-Chief Scientist), Department of Geophysics, Texas A\&M University, College Station, Texas; David A. Johnson (Co-Chief Scientist), Department of Geology and Geophysics, Woods Hole Oceanographic Institution, Woods Hole, Massachusetts; Pavel Č epek, Bundesanstalt für Geowissenschaften und Rohstoffe, Hannover, Federal Republic of Germany; William T. Coulbourn, Deep Sea Drilling Project, Scripps Institution of Oceanography, La Jolla, California; Luiz A. Gamboa, Lamont-Doherty Geological Observatory, Palisades, New York, (present address: Center for Marine Crustal Studies, Gulf Science and Technology, Pearl River, New York); Norman Hamilton, Department of Geology, University of Southampton, Southampton, United Kingdom; Ubirajara de Melo, PETROBRAS, Centro de Pesquisas e Desenvolvimento, Cidade Universitária, Rio de Janiero, Brazil; Claude Pujol, Département de Géologie et Océanographie, Université de Bordeaux, 33405 Talence, France; Alexander N. Shor, Lamont-Doherty Geological Observatory, Palisades, New York; Alexey E. Suzyumov, P. P. Shirshov Institute of Oceanology, U.S.S.R. Academy of Sciences, Moscow, U.S.S.R.; R. C. Tjalsma, Exploration and Production Research Laboratory, Cities Service Company, Tulsa, Oklahoma; William H. Walton, Department of Civil Engineering, Cornell University, Ithaca, New York (present address: Charles T. Main, Inc., Boston, Massachusetts).
}

1) The oldest sediment recovered from Site 517 is late Pliocene in age. The benthic $\delta^{18} \mathrm{O}$ record between 3.1 and $2.8 \mathrm{Ma}$ does not contain the single, permanent enrichment in $\delta^{18} \mathrm{O}$ that is commonly observed in the upper Pliocene. Rather, the $\delta^{18} \mathrm{O}$ record undergoes rapid oscillation, and gradually trends toward heavier values (Hodell and Kennett, this volume). The absence of a distinct $\delta^{18} \mathrm{O}$ enrichment is puzzling, in view of the location of Site 517 within the core of modern NADW. One possible explanation is that a major phase of ice growth was completed before $3.1 \mathrm{Ma}$ and that the premature termination of Site 517 did not allow us to reach the principal "event".

2) Like the benthic record, the planktonic $\delta^{18} \mathrm{O}$ record at Site 517 also lacks the expected $\delta^{18} \mathrm{O}$ enrichment within the upper Pliocene. Leonard and others (this volume) propose a surface water temperature increase in the South Atlantic co-occurring with the buildup of ice in the northern hemisphere and a dampened $\delta^{18} \mathrm{O}$ signal resulting from the opposing effects of warming temperatures and global ice growth.

3) A vertical water mass structure for the Vema Channel in the late Pliocene (about $3.0 \mathrm{Ma}$ ) has been reconstructed by calculating gradients in $\delta^{13} \mathrm{C}$ between the surface (about $50 \mathrm{~m}$; planktonics), intermediate (1313 m; Site 516A), deep (2963 m; Site 517), and bottom (3944 m; Site 518) waters. The upper Pliocene vertical profile of $\delta^{13} \mathrm{C}$ is comparable to modern values, suggesting that the modern circulation patterns of the western South Atlantic were established by $3.0 \mathrm{Ma}$.

4) The relatively high abundance of benthic foraminifers indicative of Antarctic Bottom Water (AABW) during the late Pliocene at Site 517 suggests a relatively strong flow and/or a shallowing of AABW during the late Pliocene compared to the Pleistocene.

\section{BACKGROUND AND OBJECTIVES}

Site 517 is part of a profile of drill sites selected in order to generate a depth transect of sites in the southwestern Atlantic for analysis of changes in paleotemperature, paleoproductivity, carbonate dissolution, and ocean circulation (Fig. 1). That profile includes Site 516 on the upper part of the Rio Grande Rise (water depth about $1310 \mathrm{~m})$, Site 517 on the west flank $(2950 \mathrm{~m})$, Site $518(3950 \mathrm{~m})$, and Site 515 in the Brazil Basin (4250 m). A depth profile of these four sites shows their position with respect to the distribution of the major water masses of the South Atlantic Ocean (Fig. 2). The sites are positioned within transition zones between major water masses, and at the "core" of two of these water masses, North Atlantic Deep Water (NADW) and Antarctic Bottom Water (AABW). The lithologic, paleontologic, stratigraphic, and isotopic record at each of these sites should reflect both the rates of formation of these water masses in higher latitudes and the vertical migrations of the interfaces as a consequence of lead/lag relationships in their production rates. A similar transect of sites was drilled on the Walvis Ridge in the southeastern Atlantic on Leg 74 . The Leg 72 results complement the efforts of the Leg 74 scientists in deriving a comprehensive understanding of the tectonic and oceanographic evolution of the South Atlantic during the Cenozoic. 


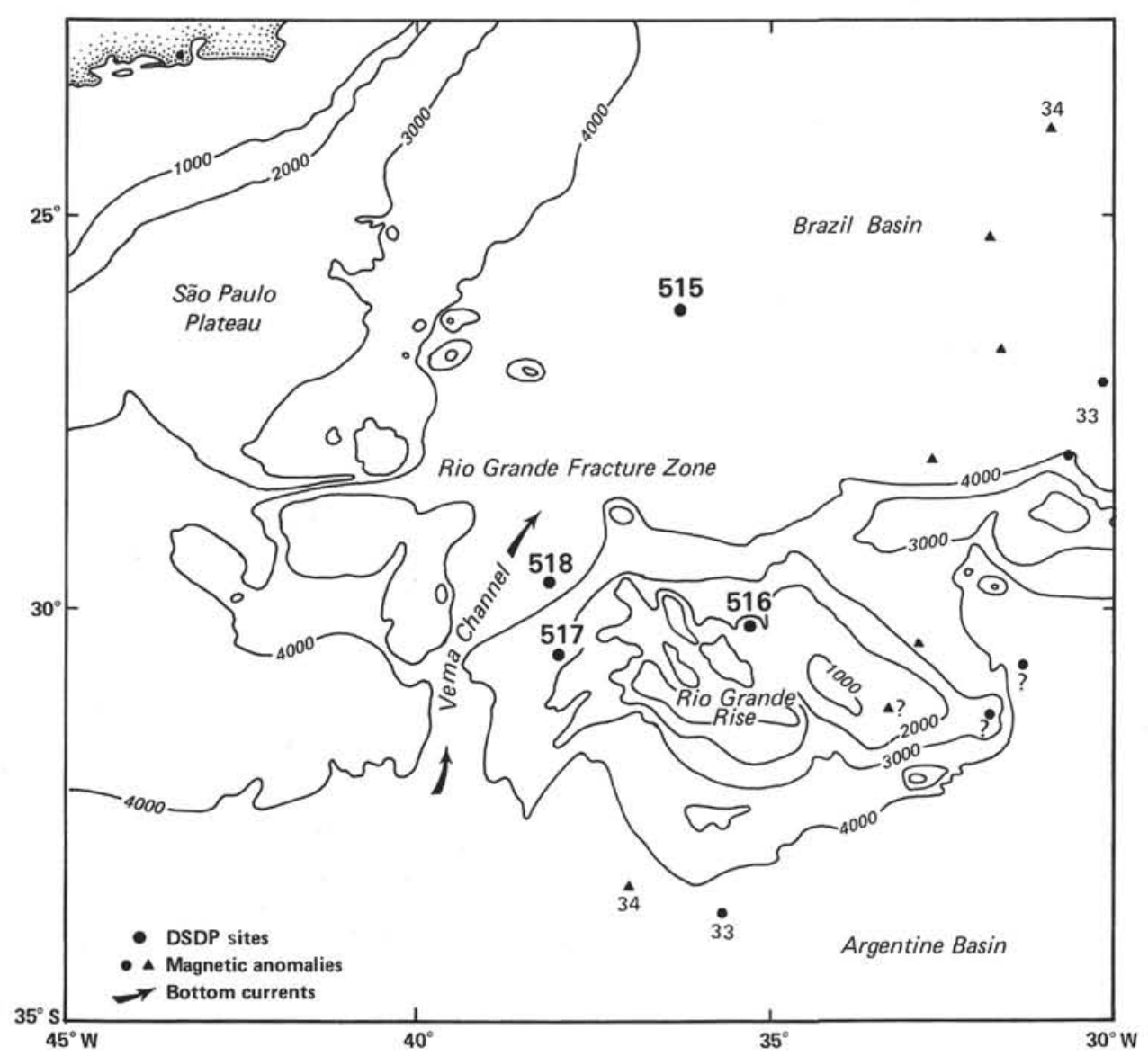

Figure 1. Location map showing positions of Leg 72 sites, marine magnetic anomalies, and generalized bathymetry.

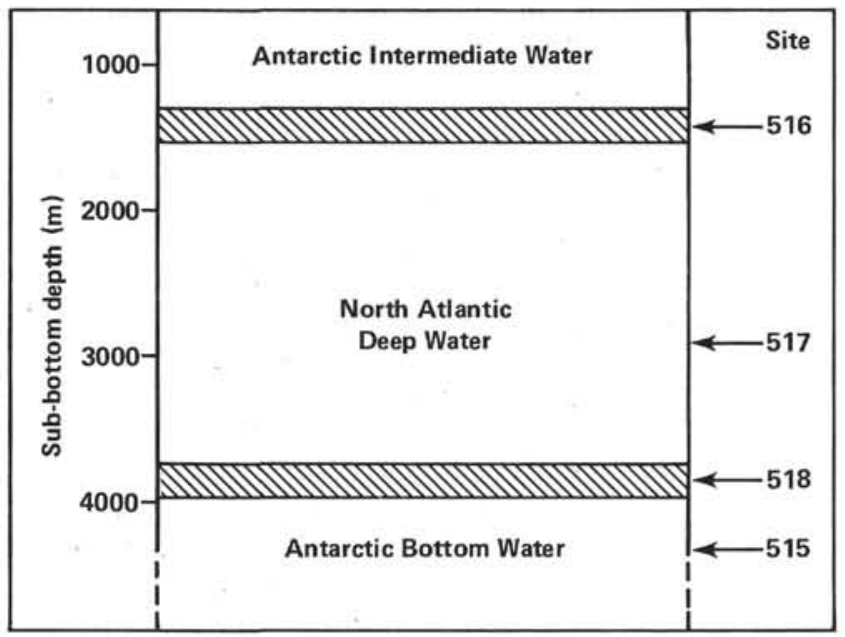

Figure 2. Water depth at Leg 72 drill sites with respect to the vertical distribution of the major water masses of the South Atlantic Ocean.

Site 517 is located to coincide approximately with the position of Core CHN 115-88, a 7-m piston core whose lithologic, stratigraphic, and isotopic record for the upper Pleistocene (down to $700,000 \mathrm{Ma}$ ) has been previously reported (Peters, 1976; Johnson et al., 1977;
Lohmann, 1978; Williams and Ledbetter, 1979; Ledbetter, 1979).

The flanks of the Rio Grande Rise are particularly appropriate sites for monitoring NADW production, because steady southward flow at intermediate depths is well defined near $30^{\circ} \mathrm{S}$ (Reid et al., 1977). Moreover, there are relatively few topographic rises in the North and Central Atlantic with sufficiently smooth basement relief and a sufficiently thick pelagic sediment cover to intercept NADW at appropriate depths. Because the site lies within southward-flowing, relatively oxygen-rich, and $\mathrm{CO}_{2}$-depleted NADW, the dissolution of calcareous microfossils and the microfossil and lithologic components should bear a direct relationship to the timing and production rates of that water mass.

Specific questions explored by drilling at Site 517 include:

1) How is the production of NADW in the northernmost Atlantic reflected in the dissolution characteristics of the calcareous microfossil constituents on the Rio Grande Rise?

2) Have the properties of NADW changed with time, or is it an essentially uniform water mass whose production rates have changed?

3) What are the phase relationships between NADW formation and the major glacial/interglacial climatic fluctuations of the late Cenozoic? What do these rela- 
tionships imply regarding the oceanographic conditions favorable to maximum NADW production and maximum $\mathrm{CO}_{2}$ extraction from the atmosphere?

4) Does the isotopic record support the evidence of Shackleton and Opdyke (1977), which implies an initiation of northern hemisphere glaciation at $3.2 \mathrm{Ma}$ ?

5) How did the intermediate waters of the South Atlantic respond to the full development of Antarctic glaciation during the Miocene?

\section{OPERATIONS}

We approached Site 517, on the western flank of the Rio Grande Rise, on a heading of $231^{\circ}$ and dropped the beacon at $1654 \mathrm{Z}$ on 30 March 1980 on our first pass over the site (Fig. 3). The hole was spudded in at $2340 \mathrm{Z}$ on $30 \mathrm{March}$, and we commenced continuous HPC coring as planned.

In view of the very short time remaining for drilling operations, we planned to use the hydraulic piston corer (HPC) at Site 517 until middle to late Miocene sediments were recovered, then move downslope to Site 518. By $1430 \mathrm{Z}$ on 31 March, we had recovered 12 cores, the deepest late Pliocene in age; however, wind and sea conditions prevented further coring operations. When the hole was abandoned by clearing the mudline at $1157 \mathrm{hr}$. (1457Z) on 31 March, we had cored $50.9 \mathrm{~m}$ and recovered $48.49 \mathrm{~m}(95 \%)$ of calcareous, biogenic ooze (Table 1).

While we were retrieving the drill string, the ship drifted several miles to the west of Site 517 before we
Table 1. Coring summary, Site 517.

\begin{tabular}{cccccccc}
\hline & $\begin{array}{c}\text { Date } \\
(\text { March } \\
\text { Core }\end{array}$ & $\begin{array}{c}\text { Time } \\
\text { 1980) }\end{array}$ & $\begin{array}{c}\text { Depth from } \\
\text { drill floor } \\
(\mathrm{m})\end{array}$ & $\begin{array}{c}\text { Depth below } \\
\text { seafloor } \\
(\mathrm{m})\end{array}$ & $\begin{array}{c}\text { Length } \\
\text { cored } \\
(\mathrm{m})\end{array}$ & $\begin{array}{c}\text { Length } \\
\text { recovered } \\
(\mathrm{m})\end{array}$ & $\begin{array}{c}\text { Core } \\
\text { recovered } \\
(\%)\end{array}$ \\
\hline 1 & 31 & 0303 & $2970.4-2972.9$ & $0.0-2.5$ & 2.5 & 2.51 & $100+$ \\
2 & 31 & 0428 & $2972.9-2977.3$ & $2.5-6.9$ & 4.4 & 3.57 & 81 \\
3 & 31 & 0528 & $2977.3-2981.7$ & $6.9-11.3$ & 4.4 & 2.22 & 50 \\
4 & 31 & 0630 & $2981.7-2986.1$ & $11.3-15.7$ & 4.4 & 4.62 & $100+$ \\
5 & 31 & 0733 & $2986.1-2990.5$ & $15.7-20.1$ & 4.4 & 4.66 & $100+$ \\
6 & 31 & 0828 & $2990.5-2994.9$ & $20.1-24.5$ & 4.4 & 4.58 & $100+$ \\
7 & 31 & 0935 & $2994.9-2999.3$ & $24.5-28.9$ & 4.4 & 4.20 & 95 \\
8 & 31 & 1045 & $2999.3-3003.7$ & $28.9-33.3$ & 4.4 & 4.52 & $100+$ \\
9 & 31 & 1130 & $3003.7-3008.1$ & $33.3-37.7$ & 4.4 & 4.49 & $100+$ \\
10 & 31 & 1223 & $3008.1-3012.5$ & $37.7-42.1$ & 4.4 & 3.94 & 90 \\
11 & 31 & 1321 & $3012.5-3016.9$ & $42.1-46.5$ & 4.4 & 4.62 & $100+$ \\
12 & 31 & 1423 & $3016.9-3021.3$ & $46.5-50.9$ & 4.4 & 4.56 & $100+$ \\
& & & & & 50.9 & 48.49 & 95 \\
\hline
\end{tabular}

got underway for Site 518 on a heading of $027^{\circ}$, at 1706 hr. (2006Z) on 31 March.

\section{SEDIMENT LITHOLOGY}

\section{Unit 1. Foraminiferal-Nannofossil Ooze} (0-50.9 m sub-bottom)

Only one lithologic unit was recovered in Cores 1-12 at Site 517 (Fig. 4). The foraminiferal-nannofossil ooze at that location is light yellowish brown (10YR 6/4) to very pale brown $(10 \mathrm{YR} 7 / 3)$ in the upper cores, becoming generally white $(10 \mathrm{YR} 8 / 1)$ with isolated darker mottles of very pale brown (10YR 7/3) sediment in the lower part of the section (Cores 6 through 12). Mottles may be due to coring disturbance or to bioturbation. Clay minerals are more abundant in Core 1 than else-

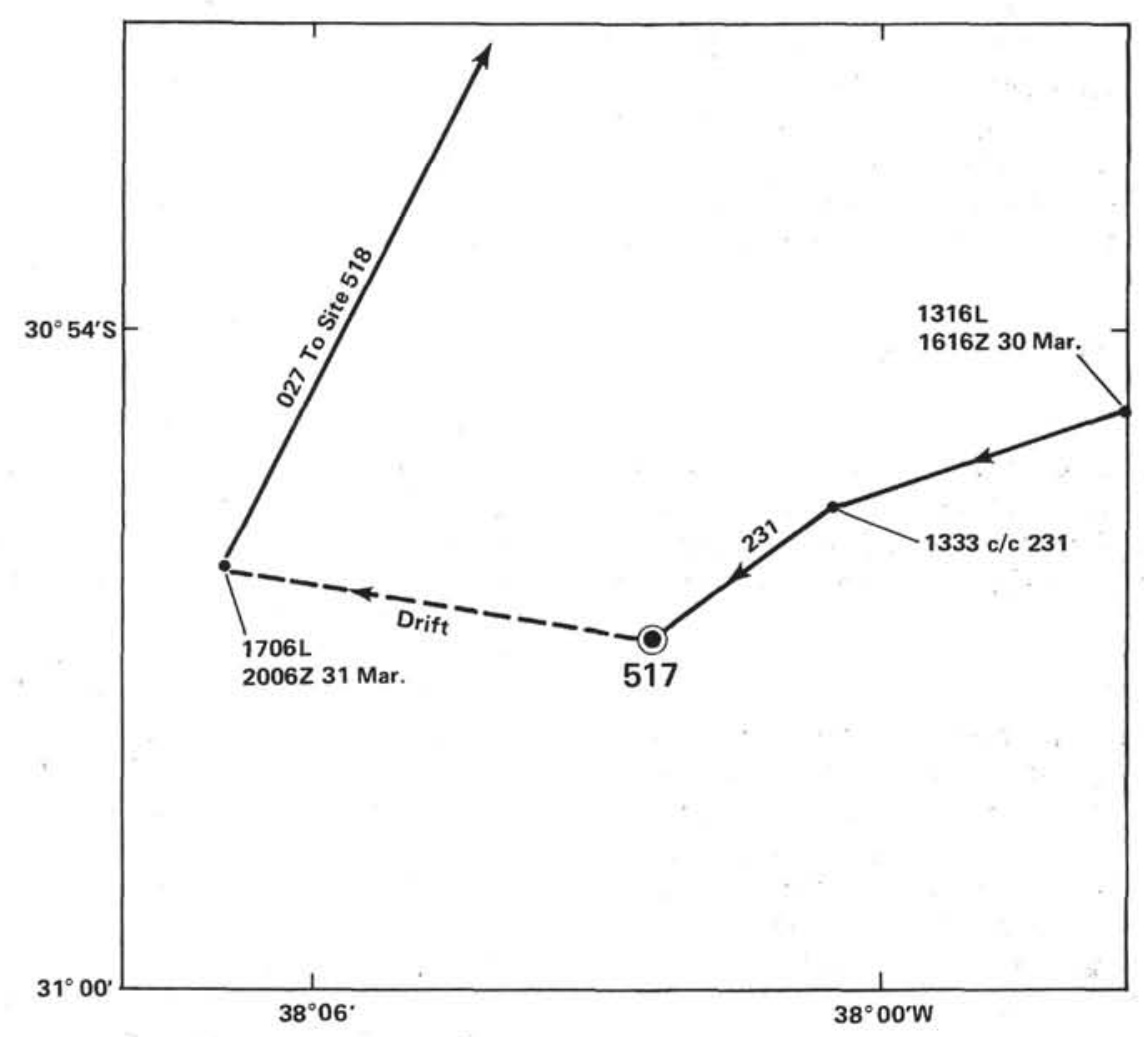

Figure 3. Approach and departure, Site 517. $\mathrm{c} / \mathrm{c}=$ course change. 


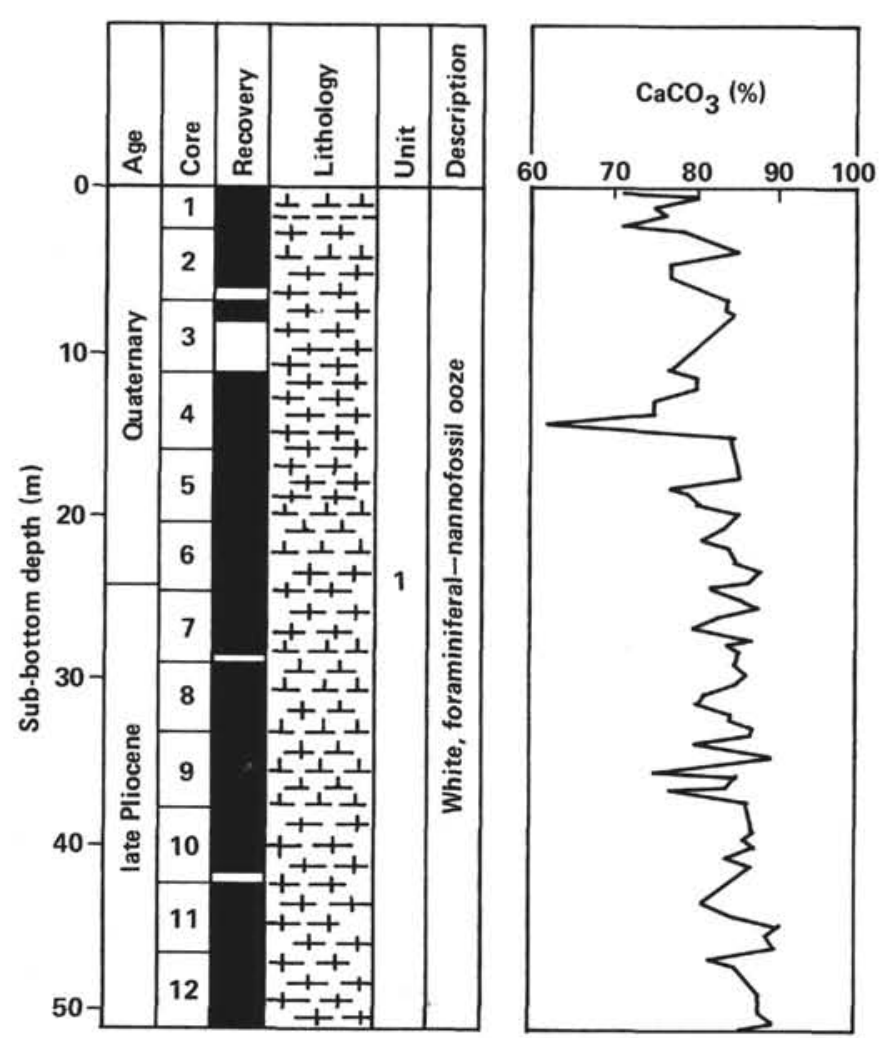

Figure 4. Summary lithologic column and percent carbonate at Site 517.

where in the section. The deposit is pelagic, and there is no evidence of bottom or turbidity currents. The relative abundance of foraminifers is variable, ranging from $3 \%$ in Section $517-2-1$ to only $1 \%$ in Section $517-9-2$. Similarly, the nannofossil concentration varies from $87 \%$ in Section $517-7-2$ to $35 \%$ in Section $517-1-1$. Pteropods and aragonite needles attest to the excellent preservation of the deposit.

\section{SEDIMENTARY GEOCHEMISTRY}

\section{Carbonate Analysis}

Eighty-three carbonate bomb analyses were made on samples from Hole 517. Those data are plotted in Figure 4 , and values are listed on the core description forms accompanying this chapter; the precision is estimated to be $\pm 1 \%$.

\section{X-Ray Diffraction Analysis}

X-ray diffractograms for samples from Cores 1, 2, 4, $6,8-10$, and 12 show peaks for calcite. Although pteropods and aragonite needles were noted in the smear slide descriptions, aragonite peaks were not registered in the diffractograms. Calcite dominates the mineral assemblage within the intervals sampled at Site 517, and X-ray diffraction analysis of bulk samples may not register peaks of minor components.

\section{BIOSTRATIGRAPHY}

A total of 12 HPC cores were obtained at Site 517 on the west flank of the Rio Grande Rise. Core quality was relatively poor in the uppermost several meters but improved toward the bottom of the cored interval. A repeated lithologic succession of gray pteropod-foraminiferal ooze (representing surface sediment) overlying brown foraminiferal-nannofossil ooze indicated that Core 1 penetrated the seafloor interface at least four times before its retrieval. In some cores, several tens of centimeters of sediment were inadvertently extruded from the core liner and into the core barrel or onto the rig floor during the horizontal extrusion of the liner from the barrel. As a result, core recovery is not uniformly high in each of the 12 cores recovered and any minor "unconformities" present are probably artifacts of the core handling process rather than representative of actual erosional events on the seafloor.

With the above considerations in mind, we examined the recovered cores for all calcareous microfossil groups; they had no unconformities at the degree of resolution afforded by sample selection. The oldest sediment recovered is late Pliocene in age (Zones NN15 and PL3; 3.1 m.y.).

Microfossil preservation is uniformly good throughout the cored interval, and there is no evidence of significant reworking of older material. Fragmentation of foraminifers is variable downcore, possibly as a consequence of pulses in the production of $\mathrm{O}_{2}$-rich NADW.

\section{Nannoplankton}

Calcareous nannofossils were identified in all 12 cores of HPC Site 517. The nannoplankton are abundant and well preserved. The Tertiary zonation is the same as that used for Site 516 (see Berggren, Aubry, and Hamilton, this volume). For stratigraphic age determinations, 14 samples were investigated, and 5 calcareous nannofossil zones of 2 biostratigraphic intervals were identified:

1) Quaternary (Sections 517-1-1 through 517-6,CC; 0-24.5 m)

2) upper Pliocene (Sections 517-7, CC through 517$12, \mathrm{CC} ; 28.9-50.9 \mathrm{~m}$ )

\section{Quaternary}

Well-preserved and abundant Quaternary calcareous nannoplankton assemblages occur between the top of Core 1 and the core catcher of Core 6 . The youngest assemblages from the tops of Cores 1 and 2 contain $\mathrm{Ge}$ phyrocapsa oceanica but lack Pseudoemiliania lacuno$s a$, indicating the $G$. oceanica Zone (NN20). Existing resolution allows no more exact refinement than the Emiliania huxleyi/G. oceanica Zone. The base of the Quaternary is represented with the $P$. lacunosa Zone (NN19) in Cores 2 to 6 . The presence of $P$. lacunosa and absence of all discoasters characterize that zone.

\section{Upper Pliocene}

The last occurrence of Discoaster brouweri in Sample 517-7, CC defines the end of the upper Pliocene and also the top of the $D$. brouweri Zone (NN18). The last occurrence of $D$. pentaradiatus and $D$. asymmetricus defines the base of this zone. Both species are present in Sample $517-8, C C$ and co-occur with $D$. surculus, the index fossil (last occurrence) of the D. surculus Zone (NN16). 
There is no evidence regarding the $D$. pentaradiatus Zone (NN15). Perhaps a small hiatus occurs between Samples $517-7, C C$ and $517-8, C C$ (4.4 m of sediment). The base of Zone NN16 is present in Sample 517-11,CC. The presence of Reticulofenestra pseudoumbilica without Ceratolithus tricorniculatus assigns Sample 517-12, $\mathrm{CC}$ to the $R$. pseudoumbilica Zone (NN15).

\section{Planktonic Foraminifers}

Well-preserved foraminiferal assemblages are contained in the stratigraphic sequence ranging from $\mathrm{Re}$ cent through upper Pliocene in all 12 cores from Site 517. The zonation of Berggren (1973; 1977a, b) is used for the Pliocene, and Blow's (1969) for the Quaternary sequence. A few biozones or episodes are somewhat different; they are based on variations in the frequency of occurrence of some key species (Pujol and Duprat, this volume).

\section{Quaternary}

Quaternary sediments are present in Core 517-1 to Section 517-7-2. The assemblage contains Globorotalia truncatulinoides with some subtropical and transitional species. In this sequence, the first occurrence of G. hirsuta determines Zone N23 (mudline to Section 517-2-1). So defined, Zone N23 begins at about $0.450 \mathrm{Ma}$. Below this zone, the sequence is Pleistocene (N22 Zone). The more frequent species present in this interval are: $G$. inflata, Globigerinoides conglobatus, G. ruber, Globigerina bulloides, Globorotalia crassaformis, and Sphaeroidinella dehiscens.

\section{Pliocene}

Upper Pliocene sediments were recovered from Section 517-7-2 to Core 517-12. The Pliocene/Quaternary boundary is placed at the last occurrence of Globigerinoides obliquus (Section 517-7-3) rather than at the first appearance of Globorotalia truncatulinoides because of the likelihood of downhole contamination. On the basis of the disappearance of $G$. miocenica s.l. with increasing sub-bottom depth, Zones PL6, PL5, and PL4/PL3 are differentiated (Berggren, 1977a, b).

This zone is assessed as follows:

\begin{tabular}{ll}
\hline Zone & Core-section \\
PL6 & $\left\{\begin{array}{l}7-3 \\
8-2\end{array}\right.$ \\
PL5 & $\left\{\begin{array}{l}8-3 \\
9, C C\end{array}\right.$ \\
PL4/3 & $\left\{\begin{array}{l}10-2 \\
12, C C\end{array}\right.$
\end{tabular}

The separation of Zones PL4 and PL3 is difficult because of the scarcity of Sphaeroidinella dehiscens and some possible contamination.

\section{Benthic Foraminifers}

Benthic foraminifers are generally common and well preserved at Site 517. For comparison with Sites 515 and
516 , the census of the benthic foraminifers in a core-top sample was taken. The greater-than-149-micron fraction was counted because of the high ratio of planktonic to benthic foraminifers in the pteropod-rich surface sediment. The assemblage is dominated by Globocassidulina subglobosa, Quinqueloculina, Nummuloculina, in association with Planulina wuellerstorfi, and Oridorsalis umbonatus, Pyrgo, and Pullenia cf. bulloides. This equitable assemblage is present within much of the Pleistocene although, at least at one level (Sample 517-2,CC), $O$. umbonatus becomes dominant. Other species included in the assemblage are Uvigerina peregrina and Melonis barleanum.

The benthic assemblages of the upper Pliocene are quite distinct from those of the Quaternary. They are more diversified and are dominated by Nuttalides umbonifera rather than by G. subglobosa. Accompanying species are G. subglobosa, O. umbonatus, U. peregrina, Osangularia culter(?), Bulimina alazanensis, Eggerella bradyi, Stilostomella consobrina, Pyrgo, and Epistominella exigua. The relative abundance of Planulina wuellerstorfi decreases markedly.

In terms of water mass distribution, the Quaternary assemblage of G. subglobosa, Quinqueloculina, Nummuloculina, Pyrgo, and $P$. wuellerstorf $i$ is characteristic of NADW. The high abundance of AABW indicator species Nuttalides umbonifera, together with characteristic NADW species, such as $G$. subglobosa, $U$. peregrina, and Pyrgo, suggests the mixing of AABW and NADW during the late Pliocene at Site 517.

\section{PALEOMAGNETICS}

Paleomagnetic studies on the foraminiferal-nannofossil oozes recovered by HPC at Site 517 consist of both long-core spinning and remanence measurements on discrete samples. Thirty-one whole-core sections were rotated on the long-core spinner magnetometer unit, and 39 samples were measured from the split-core sections on the standard spinner magnetometer. Subsequent shore-based magnetic cleaning on individual samples, by thermal demagnetization techniques, was undertaken at the Geological Institute of the USSR Academy of Sciences.

Success with whole-core spinning at Site 515 prompted use of this technique again at Site 517 as the first stage of the paleomagnetic investigations. Unfortunately, the sediment lithologies here are poorly consolidated biogenous oozes. The HPC cores show numerous void intervals and evidence of coring disturbance. Hence, whole-core spinning provides data that are inferior in quality to those obtained at Site 515 . Nevertheless, below $14.5 \mathrm{~m}$ depth, reversal boundaries were detected. Investigation of the remanence inclinations of the individual sample set supplemented and confirmed these identifications. The magnetostratigraphy for this site described below is somewhat fragmentary because of the incomplete core recovery and sample disturbance.

The uppermost core is of the Brunhes Epoch, and near the terminal depth of $51 \mathrm{~m}$ the reversed polarity in Core 12 is assigned to the youngest part of the Gilbert Epoch. The base of the Jaramillo Event is between these two cores at $\mathbf{1 5 . 2}$ m sub-bottom. Reversed polarity be- 
low this boundary down to a depth of $18.5 \mathrm{~m}$ confirms the Matuyama Epoch. The base of the Olduvai Event occurs at approximately $26 \mathrm{~m}$ sub-bottom. The Gauss/ Matuyama boundary is placed at a depth of $31.1 \mathrm{~m}$. The Gauss Epoch interval is moderately well preserved down to a depth of $45.5 \mathrm{~m}$. In all likelihood, both the Kaena and the Mammoth reversed events are shown in the whole-core spinning data (see Suzyumov and Hamilton, this volume).

These magnetostratigraphic assignments result in sediment accumulation rates at Site 517 in the range of 7 to $22 \mathrm{~m} / \mathrm{Ma}$. The faster rate is encountered in the upper part of the Gauss Epoch. Natural remanent magnetization (NRM) intensity values for this site (mean $\mathbf{J}_{\mathrm{NRM}}=$ $8.8 \pm 5.0 \mathrm{~mA} / \mathrm{m}$ ) are generally higher than those of sediments of equivalent age from the Rio Grande Rise crest (Hole 516A, mean $\left.\mathrm{J}_{\mathrm{NRM}}=3.9 \pm 4.0 \mathrm{~mA} / \mathrm{m}\right)$.

\section{SEDIMENTATION RATES}

Sedimentation rates at Site 517 are based on planktonic foraminiferal and calcareous nannoplankton stratigraphy and magnetic reversals, combined by means of the Neogene time scale of Berggren, Kent, and Van Couvering (in press). Sedimentation was apparently continuous through the Pleistocene and late Pliocene, at rates varying between 7 and $22 \mathrm{~m} / \mathrm{Ma}$ and averaging 15 $\mathrm{m} / \mathrm{Ma}$ (Fig. 5). Correction of these rates for compaction is unnecessary.

Sediments are pelagic, with no sign of turbidites or reworked material, and preservation is good. Sedimentation rates are 2 to 3 times as high as for the same time period on the shoulder of the Rio Grande Rise, at Site 516.

\section{CORRELATION OF REFLECTION PROFILER DATA WITH DRILLING RESULTS}

HPC coring at Site 517 penetrated only $50.9 \mathrm{~m}$ to upper Pliocene calcareous ooze. If we assume compressional-wave velocity of $1.54 \mathrm{~km} / \mathrm{s}$, this sub-bottom depth amounts to only $0.066 \mathrm{~s}$, reaching only to just beneath the envelope of the seabed reflection, even on the stacked UTMSI profile (Fig. 6). Thus, apart from verifying the original inference from the profile, that Site 517 would yield an essentially pelagic succession without large amounts of downslope slumping, the correlation is trivial. The $3.5-\mathrm{kHz}$ profile at the site shows reflectors at 9 and $20 \mathrm{~m}$ (Fig. 7). These correspond neither to any observable change in properties in the somewhat disturbed cores recovered nor to any detectable hiatus in sedimentation.

\section{SUMMARY AND CONCLUSIONS}

Site 517 was originally proposed as one in a series of sites constituting a depth traverse of the Rio Grande Rise in the southwestern Atlantic for studies of Cenozoic lithofacies, carbonate dissolution, paleotemperature, paleoproductivity, and ocean circulation. The site was chosen at an intermediate depth on the Rise (about $2950 \mathrm{~m}$ ), corresponding in location with a piston core (CHN 115-88) that contains a continuous upper Pleistocene paleoceanographic record. The original objective

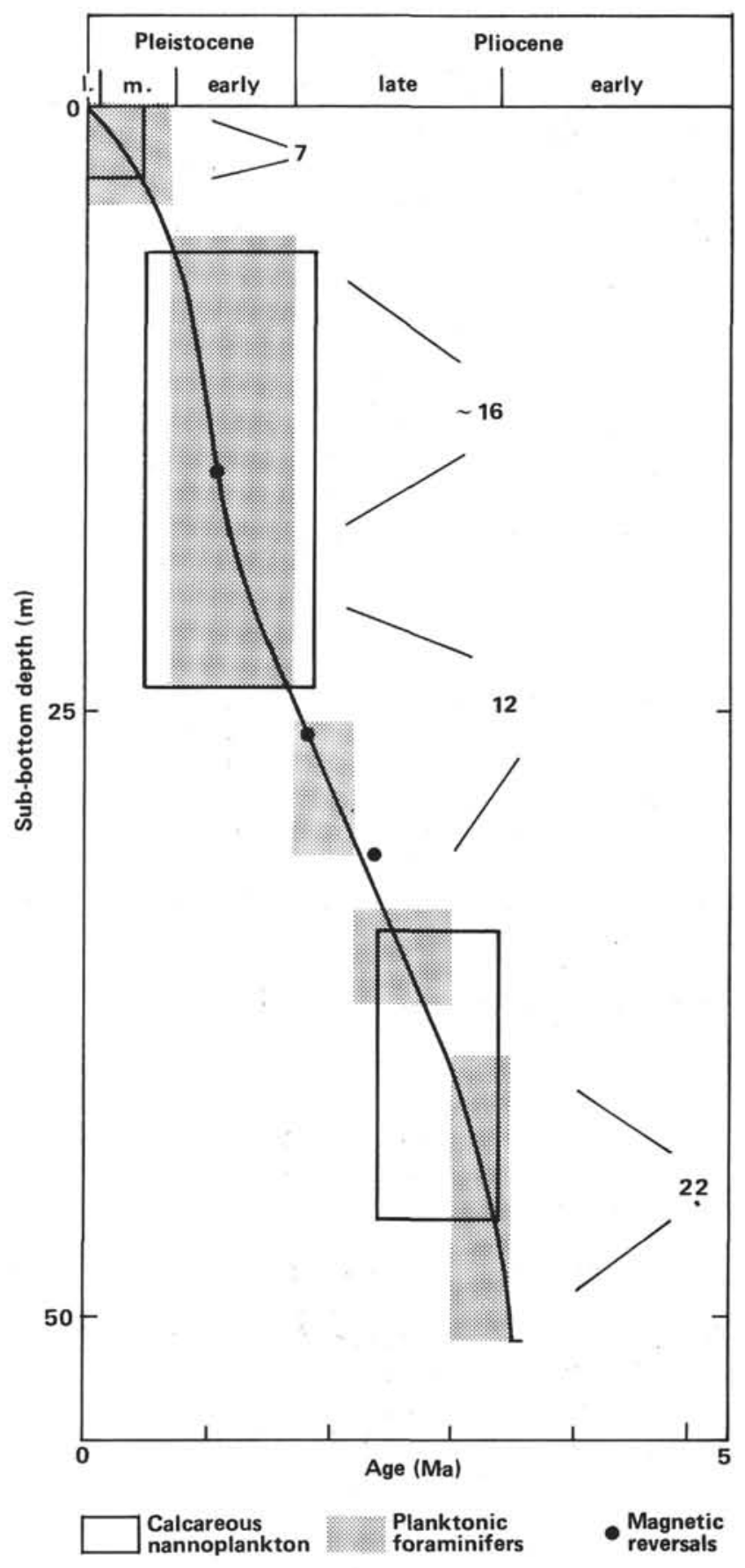

Figure 5. Sedimentation rates at Site 517.

was to continuously core this site through the Cenozoic section, to provide a lithologic and paleontologic record that complements that of the shallower (Site 516) and deeper (Site 518) regions on the Rise. Because of the time required to complete the drilling objectives at Site 516 , however, the objectives at Site 517 were modified to include HPC coring only, with a target depth of the base of the upper Miocene. Adverse weather conditions forced premature termination of coring, after obtaining $50.9 \mathrm{~m}$ of penetration. The oldest sediment recovered is mid-Pliocene (about 3.1 Ma). 


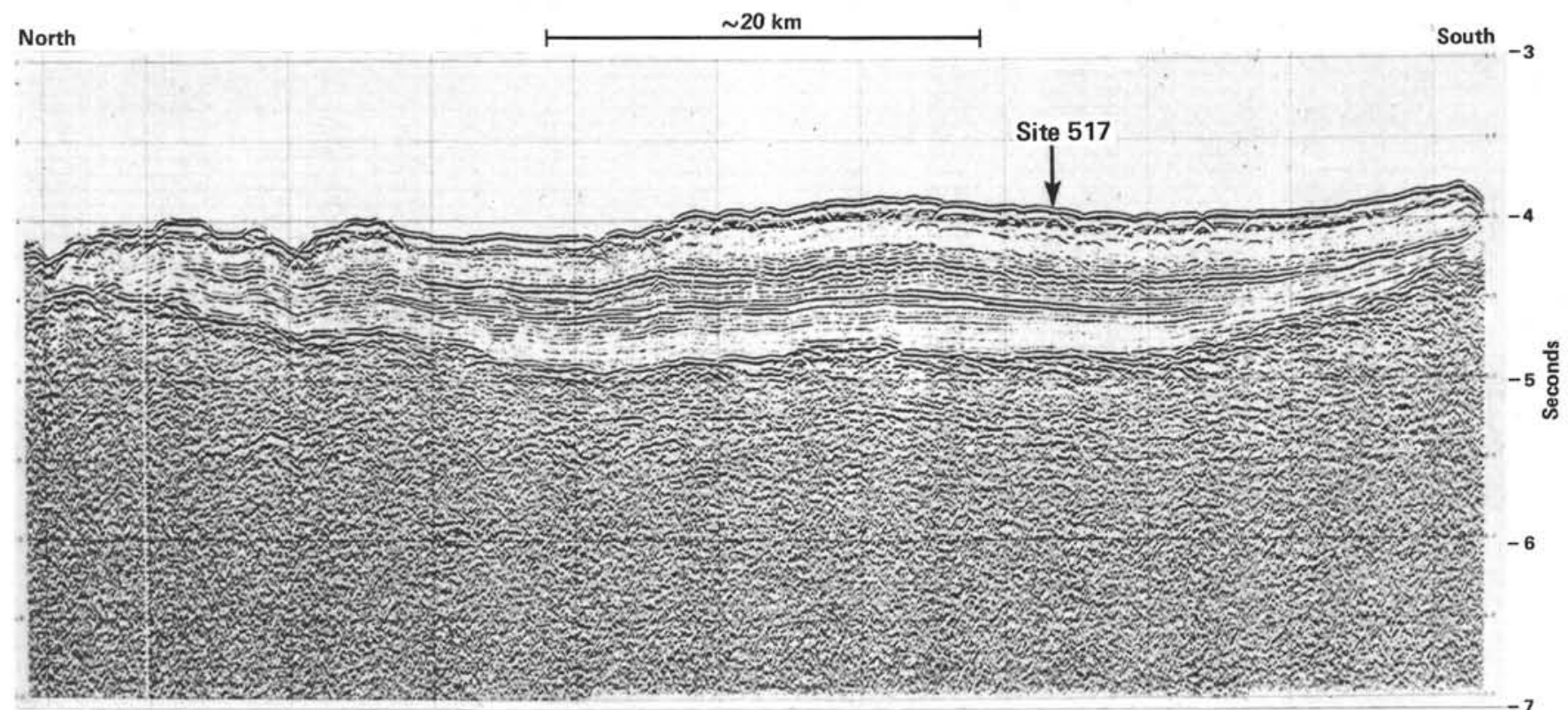

Figure 6. Multichannel seismic profile across Site 517 (UTMSI profile WSA8).

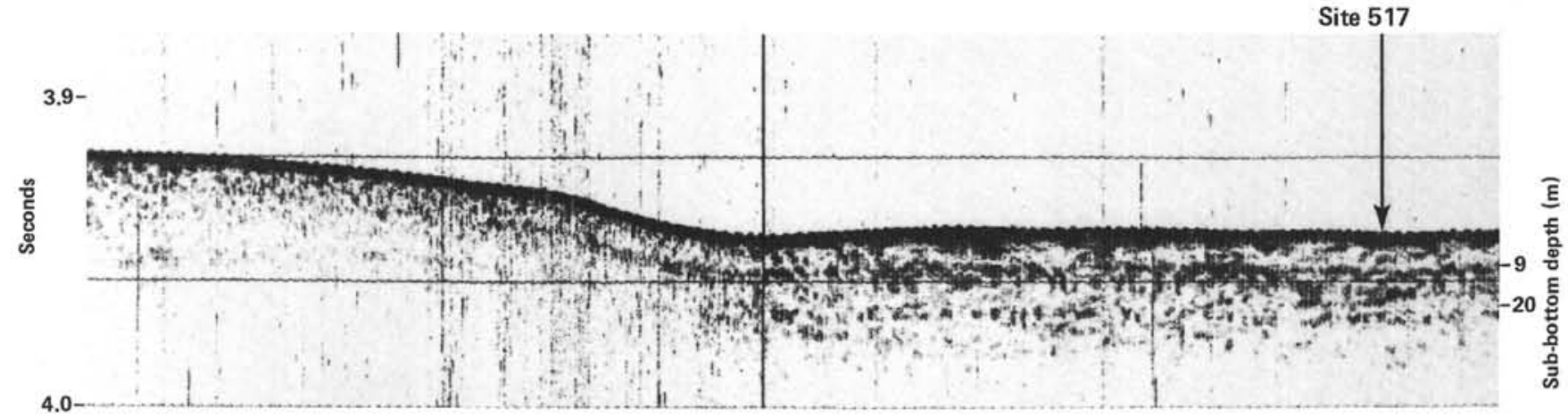

Figure 7. Glomar Challenger 3.5-kHz reflection profile across Site 517.

The lithologic unit recovered is a foraminiferal-nannofossil ooze with scattered pteropods and aragonite needles, which indicate the excellent preservation of the calcareous components. The quality of the HPC cores was poor in the uppermost several meters, but it improved downward.

Microfossil preservation is uniformly good throughout the cored interval, with no evidence for slumping or reworking of older sediment. Fragmentation of foraminifers is variable downcore, possibly as a consequence of pulses in the production of $\mathrm{O}_{2}$-rich NADW.

The Nuttalides umbonifera-dominated assemblages of the Pliocene are distinct from the Globocassidulina subglobosa-dominated assemblages of the Quaternary. The former species is diagnostic of AABW environments today, whereas the latter is characteristic of NADW, suggesting shallowing of AABW during the Pliocene.

The planktonic $\delta^{18} \mathrm{O}$ record at Site 517 does not show the expected $\delta^{18} \mathrm{O}$ enrichment in the upper Pliocene (e.g., Shackleton and Opdyke, 1977). Leonard and others (this volume) suggest that an increase in surface water temperature in the South Atlantic occurred at the same time as the buildup of ice in the northern hemisphere, and that the negligible $\delta^{18} \mathrm{O}$ signal is the result of the opposing effects of warming temperatures and global ice growth upon planktonic $\delta^{18} \mathrm{O}$ in the southwestern Atlantic.

\section{REFERENCES}

Berggren, W. A., 1973. The Pliocene time scale: calibration of planktonic foraminiferal and calcareous nannoplankton zones. Nature, 243:391-397.

, 1977a. Late Neogene planktonic foraminiferal biostratigraphy of the Rio Grande Rise (South Atlantic). Mar. Micropaleontol., 2:265-313.

1977b. Late Neogene planktonic foraminiferal biostratigraphy of DSDP Site 357 (Rio Grande Rise). In Supko, P. R. Perch-Nielsen, K., et al., Init. Repts. DSDP, 39: Washington (U.S. Govt. Printing Office), 591-614.

Berggren, W. A., Kent, D. V., and Van Couvering, J. A., in press. Neogene geochronology and chronostratigraphy. In Snelling, $\mathrm{N}$. J. (Ed.), Geochronology and the Geologic Record: London (Geol. Soc. London Spec. Publ.). 
Blow, W. H., 1969. Late middle Eocene to Recent planktonic foraminiferal biostratigraphy. In Brönnimann, P., and Renz, H. H. (Eds.), Proc. First Int. Conf. Plankt. Microfossils: Leiden (E. J. Brill), 1:199-422.

Haq, B. U., and Berggren, W. A., 1978. Late Neogene calcareous plankton biochronology of the Rio Grande Rise (South Atlantic Ocean). J. Paleontol., 52:1167-1194.

Johnson, D. A., Ledbetter, M., and Burckle, L. H., 1977. Vema Channel paleoceanography: Pleistocene dissolution cycles and episodic bottom water flow. Mar. Geol., 23:1-33.

Ledbetter, M. T., 1979. Fluctuations of Antarctic Bottom Water velocity in the Vema Channel during the last 160,000 yr. Mar. Geol., 33:71-89.

Lohmann, G. P., 1978. Abyssal benthonic foraminifera as hydrographic indicators in the western South Atlantic Ocean. J. Foraminiferal Res., 8:6-34.
Peters, C. S., 1976. Oxygen isotopic analysis of two cores from the Vema Channel: an evaluation of the method and results. WHOI Tech. Rept., No. 76-10.

Reid, J. L., Jr., Nowlin, W. D., and Patzert, W. C., 1977. On the characteristics and circulation of the southwestern Atlantic Ocean. J. Phys. Oceanogr., 7:62-91.

Shackleton, N. J., and Opdyke, N. D., 1977. Oxygen isotope and paleomagnetic evidence for early Northern Hemisphere glaciation. Nature, 270:216-219.

Williams, D. F., and Ledbetter, M. T., 1979. Chronology of late Brunhes biostratigraphy and late Cenozoic disconformities in the Vema Channel (South Atlantic). Mar. Micropaleontol., 4:125-136.

Date of Initial Receipt: November 22, 1982 


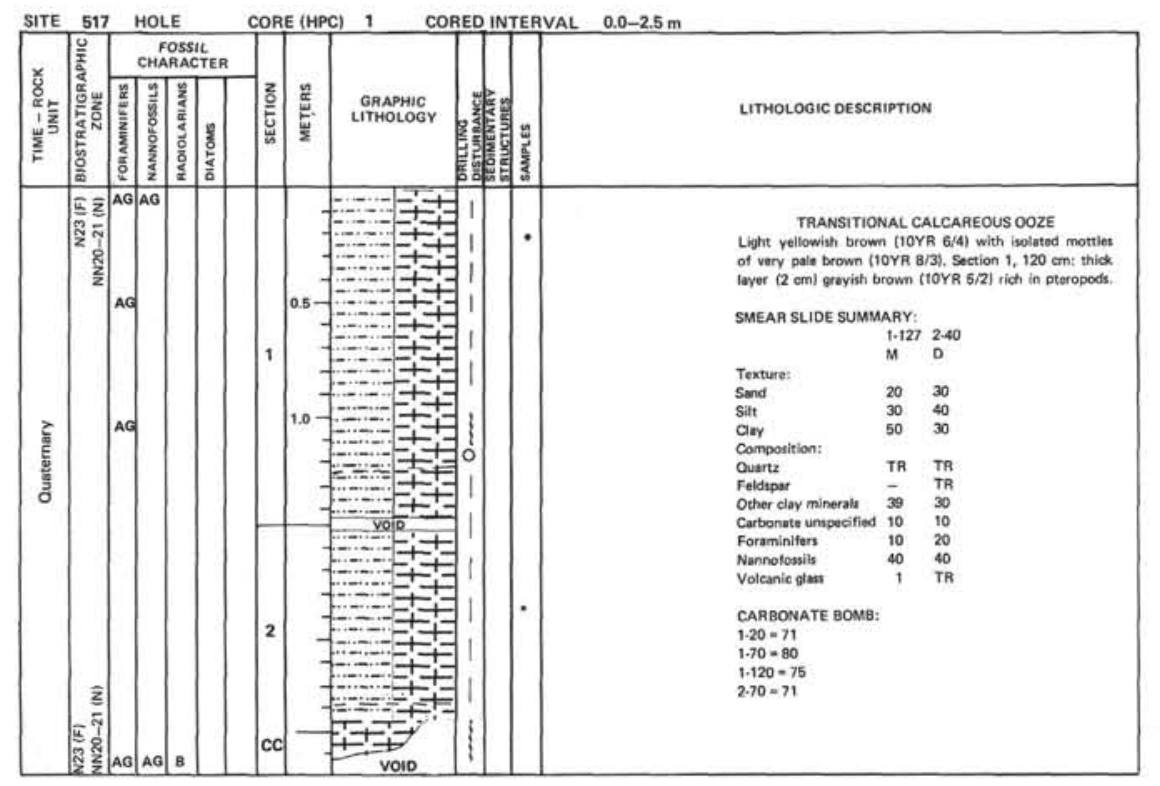

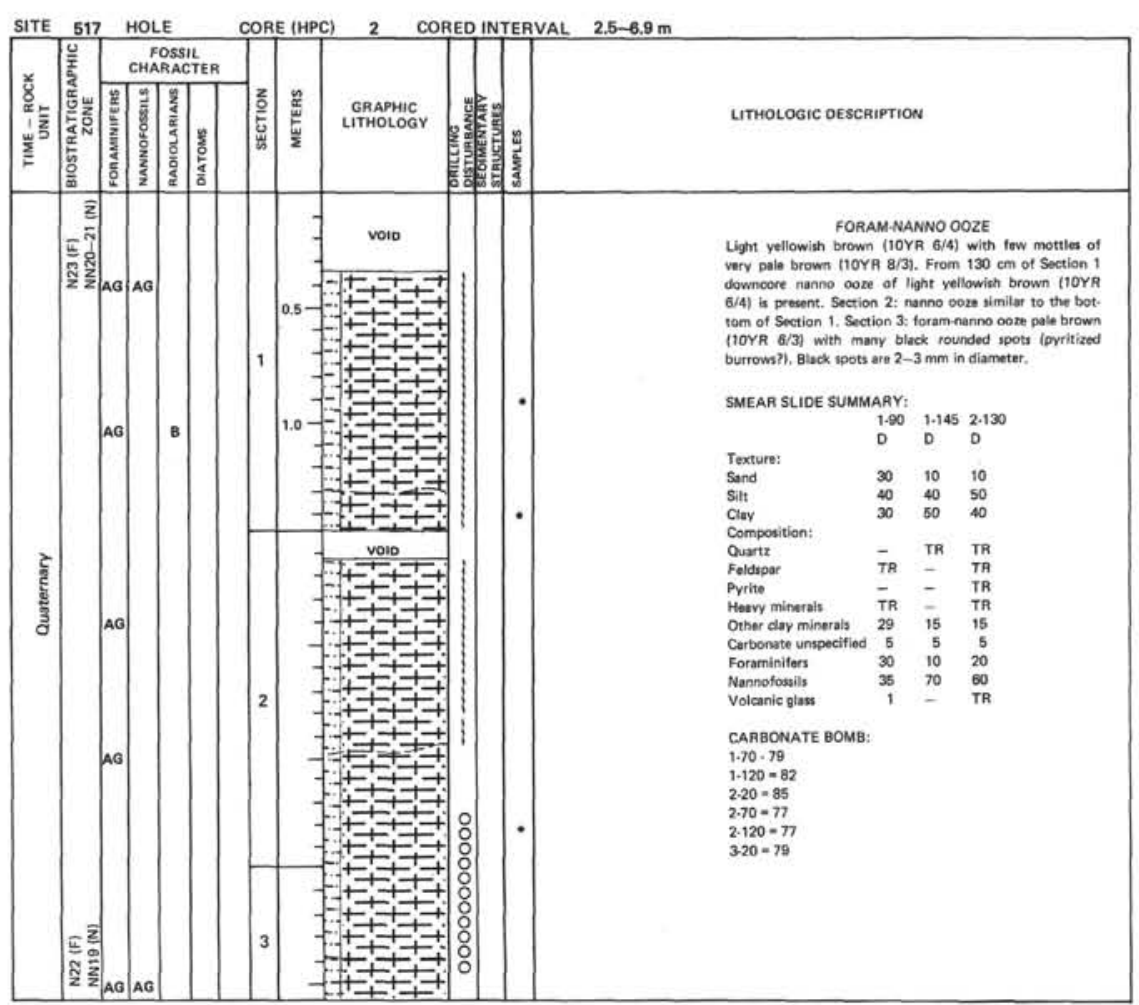




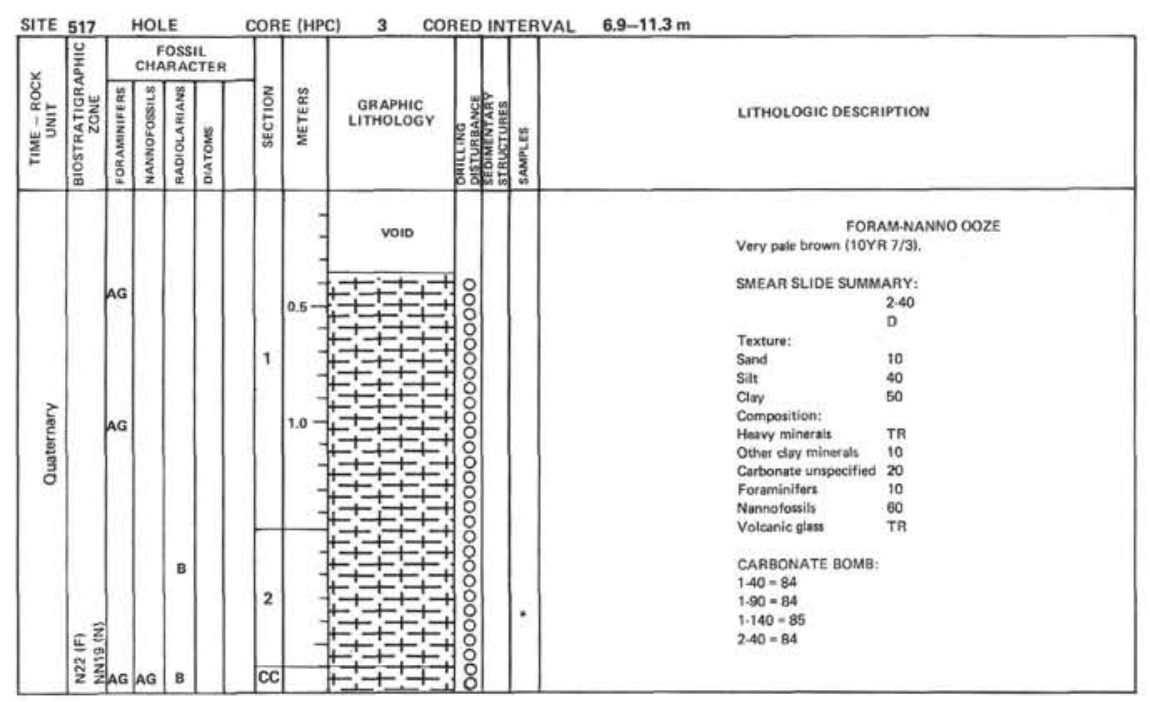

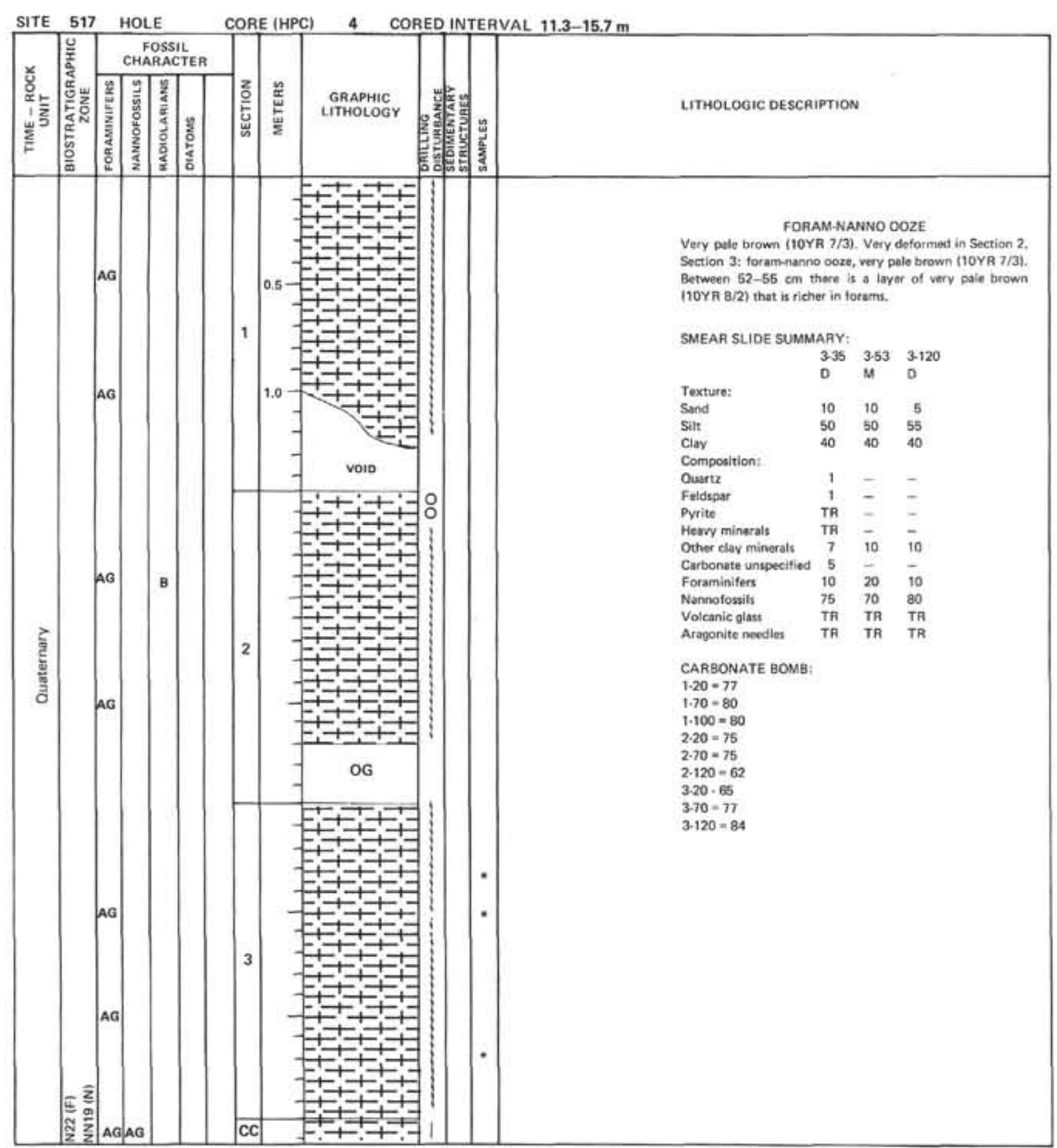




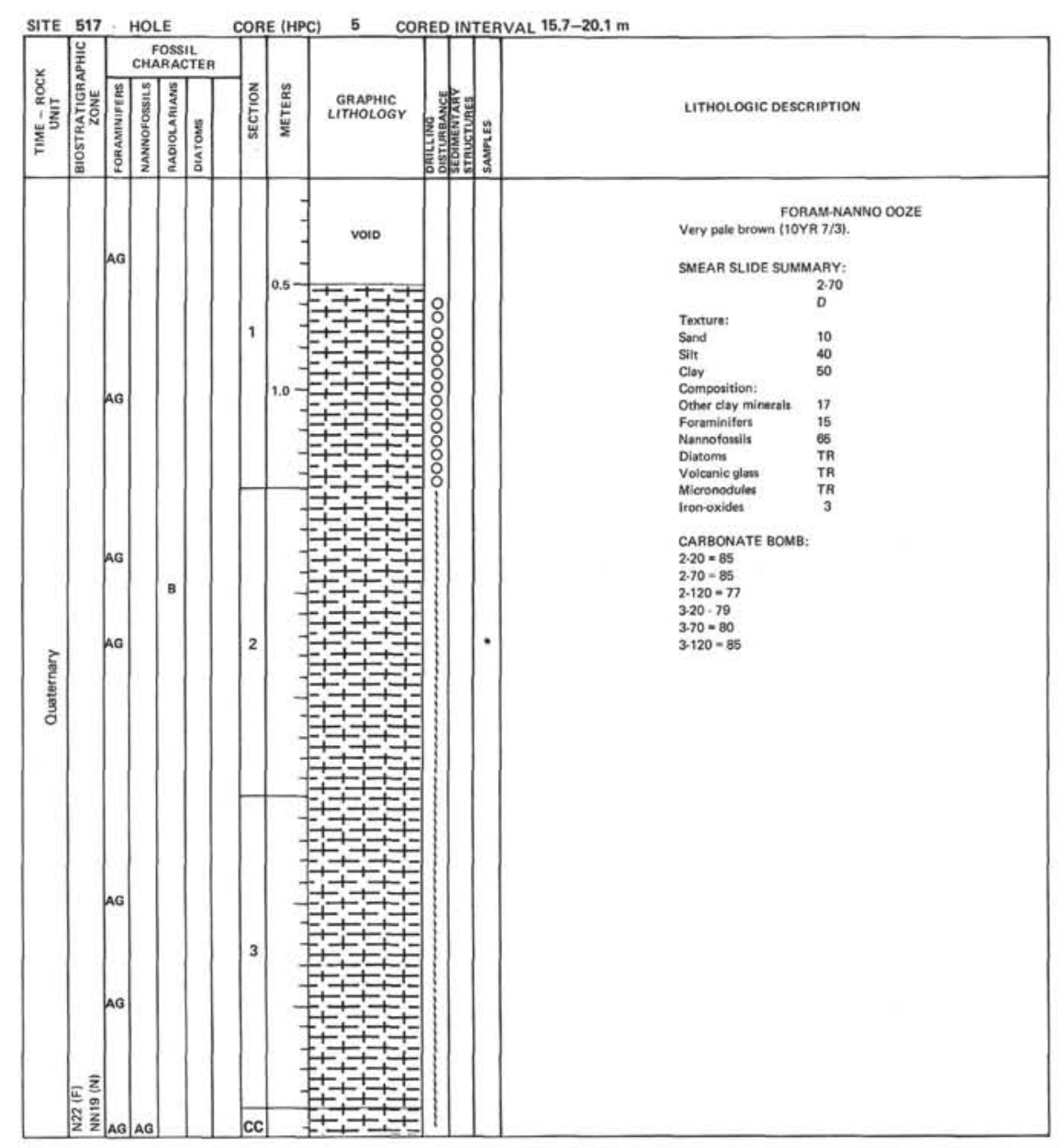

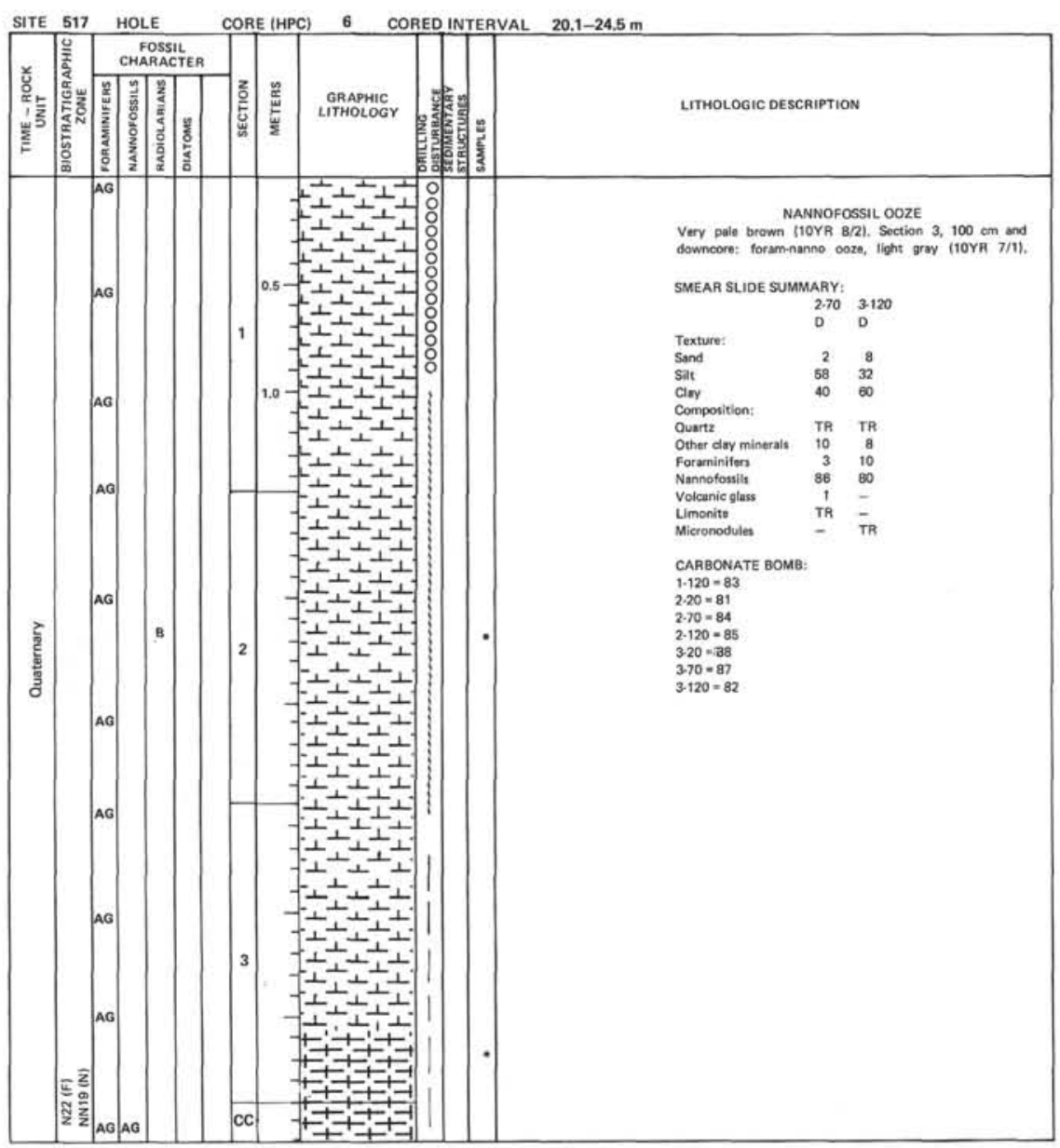




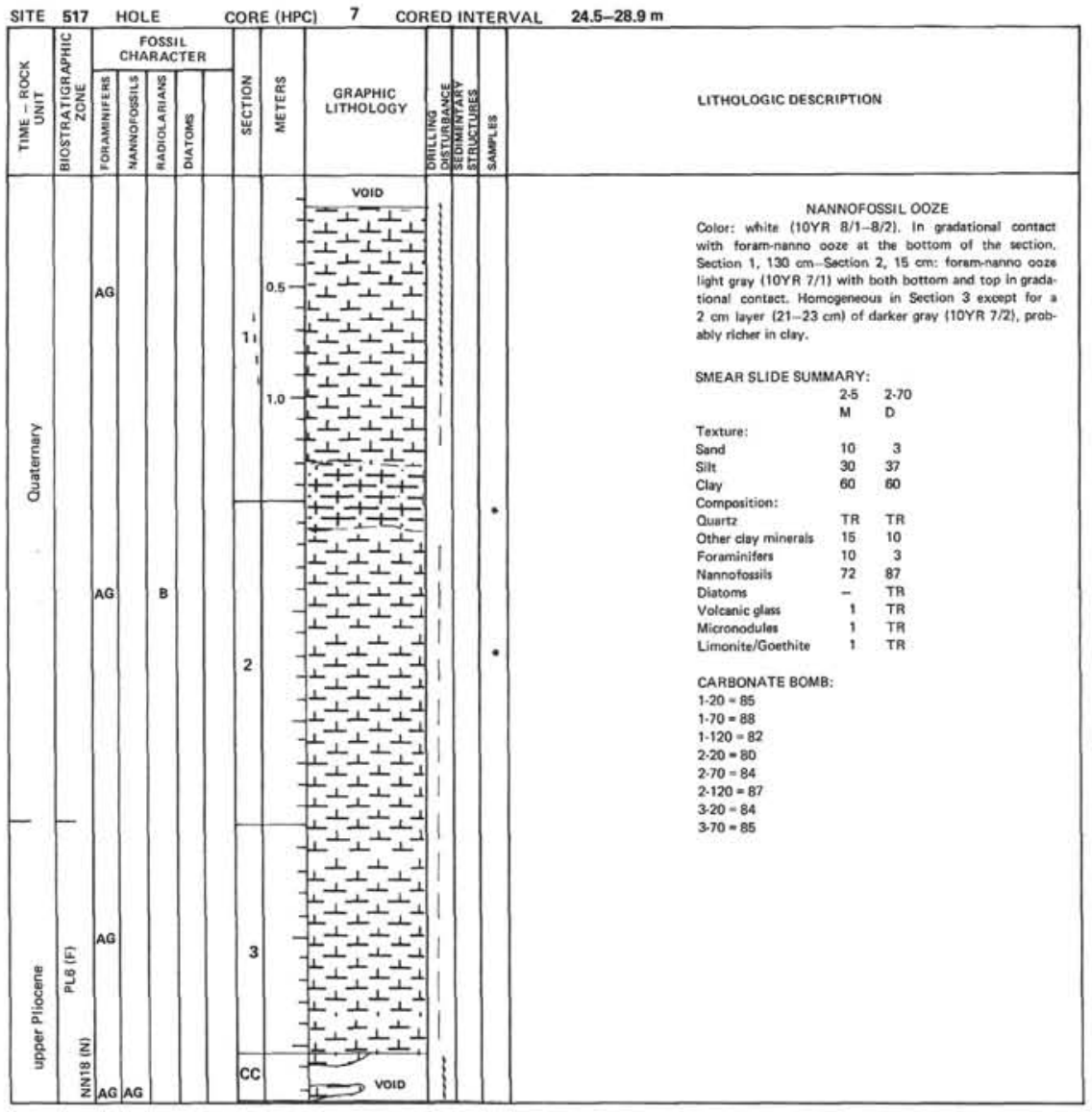

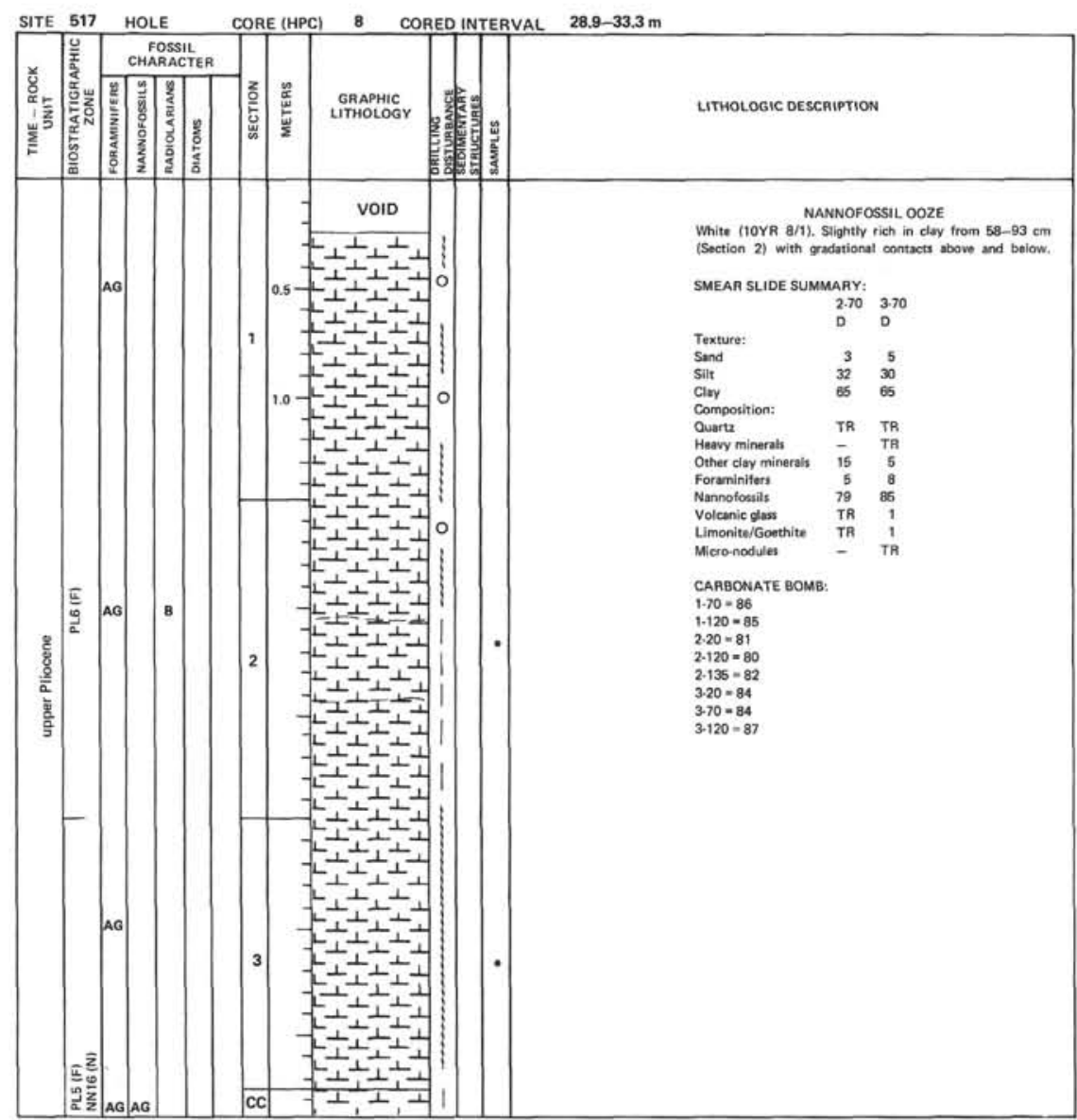




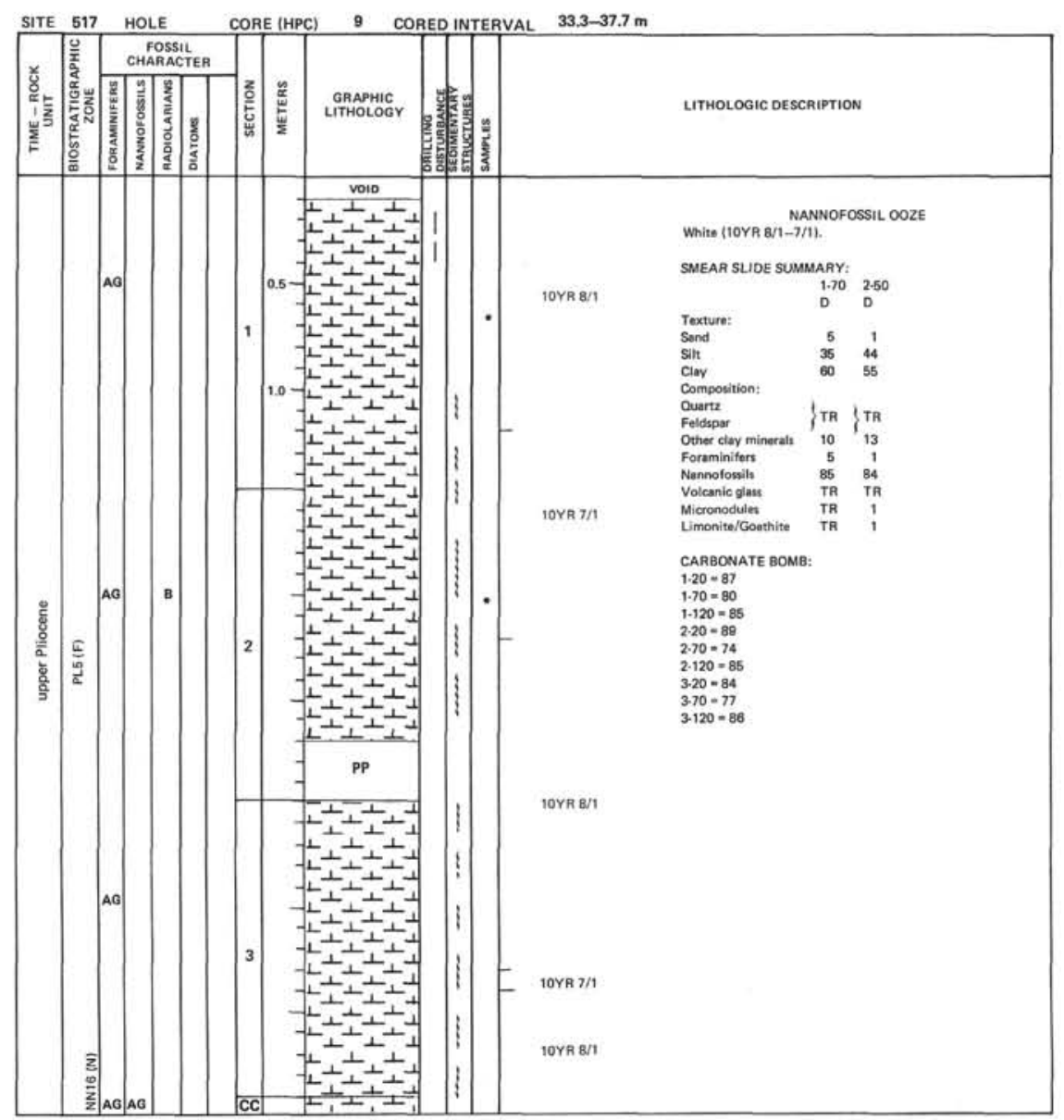

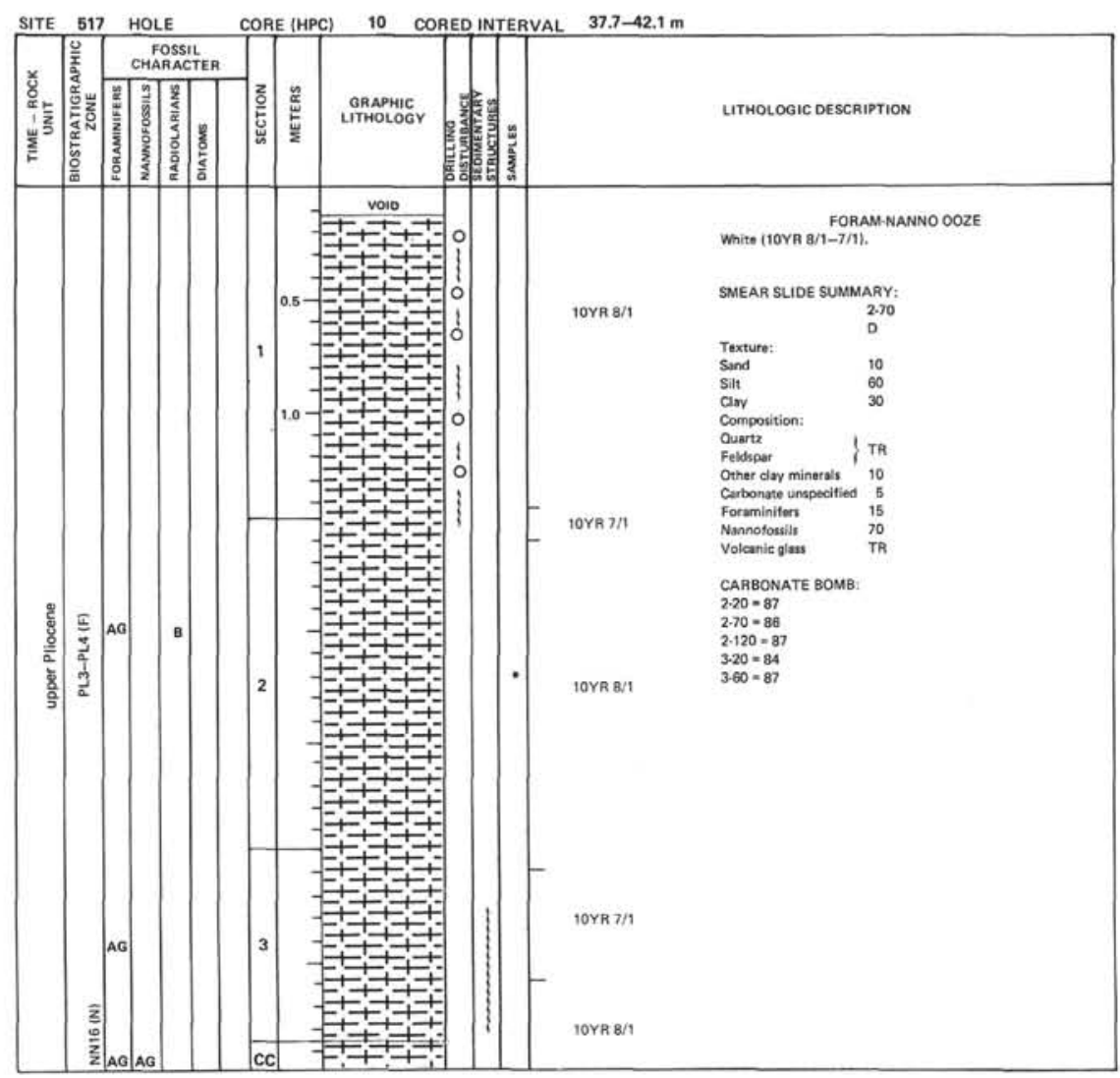



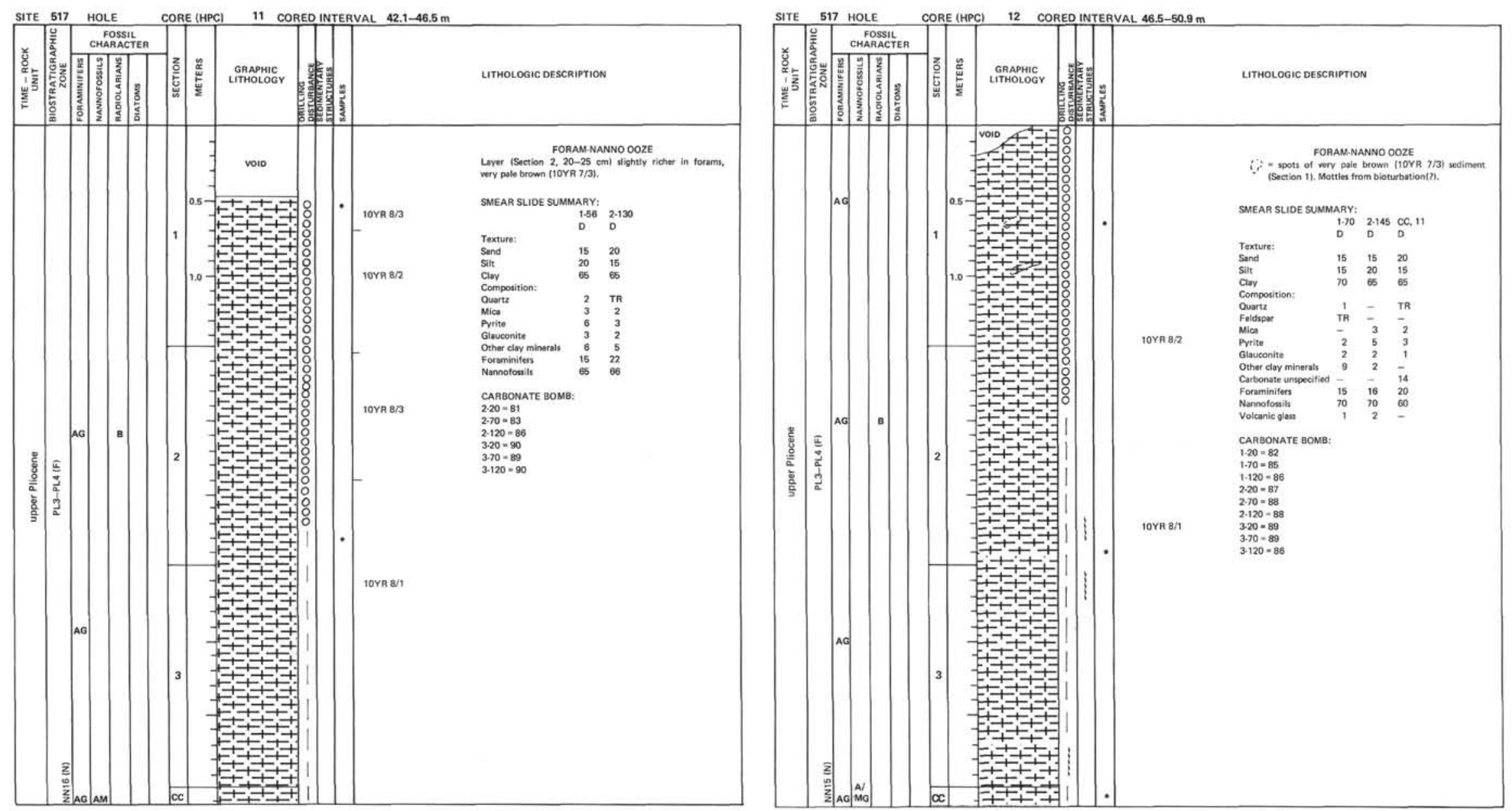
SITE 517 (HOLE 517)

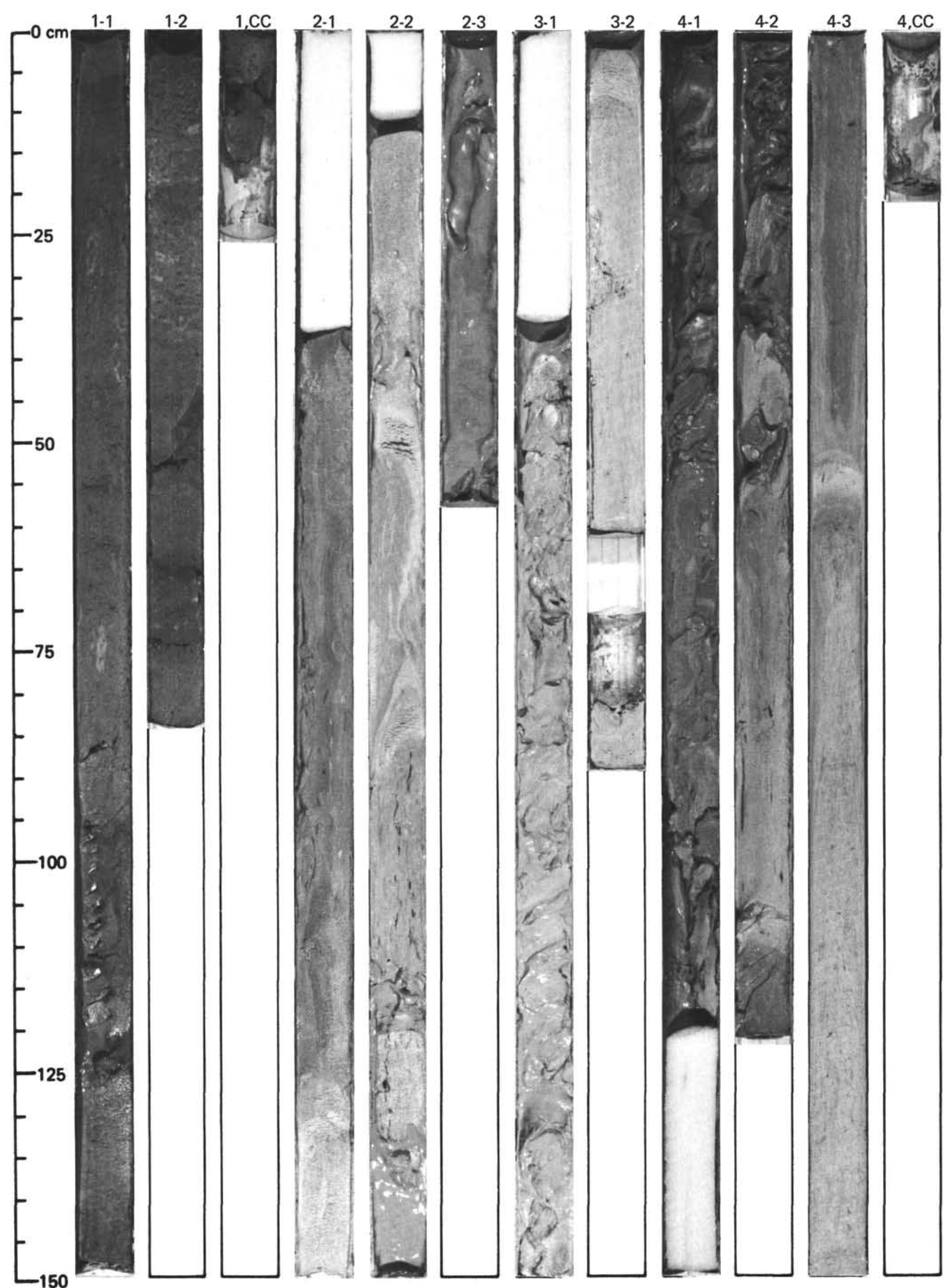




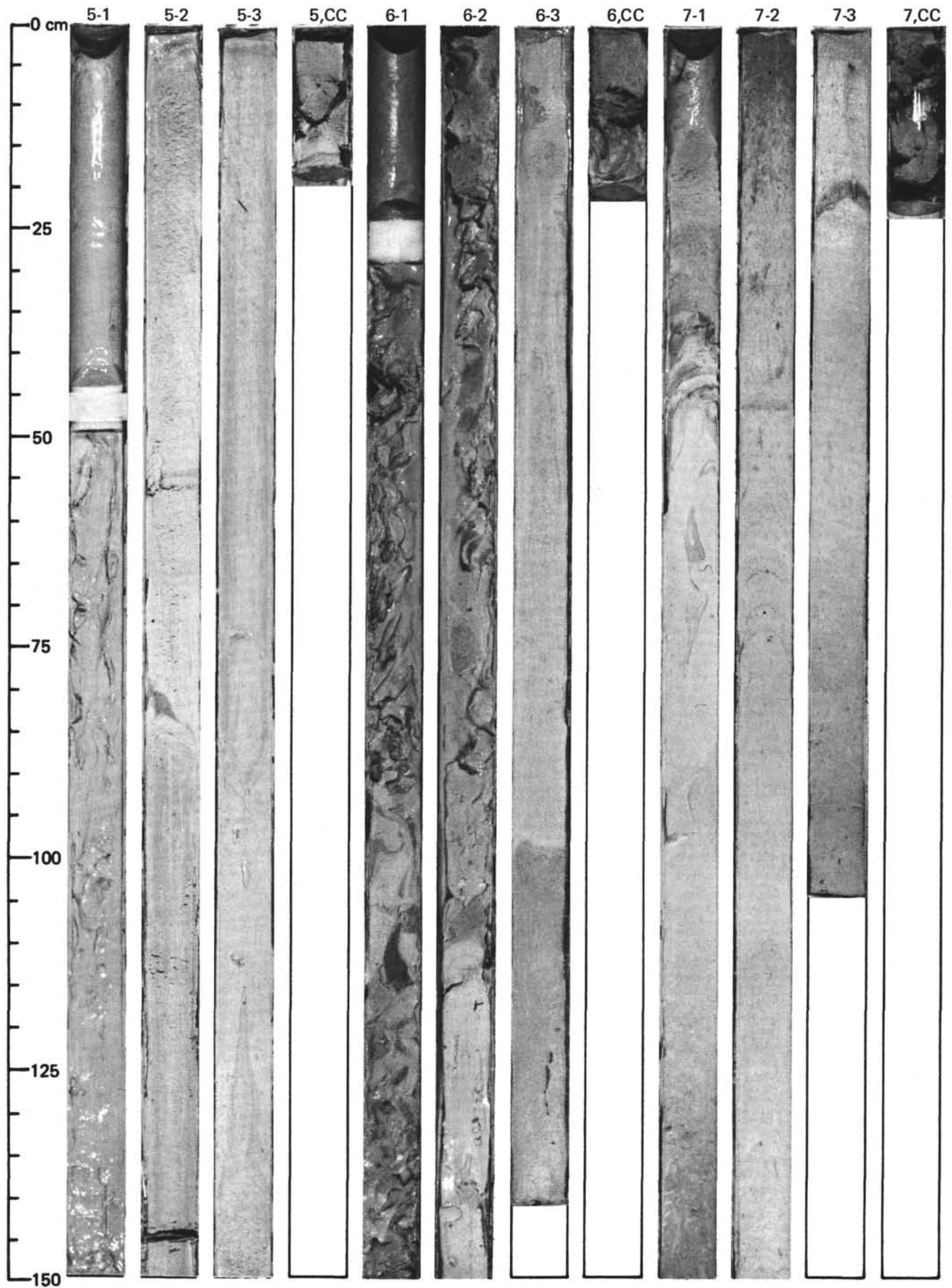


SITE 517 (HOLE 517)

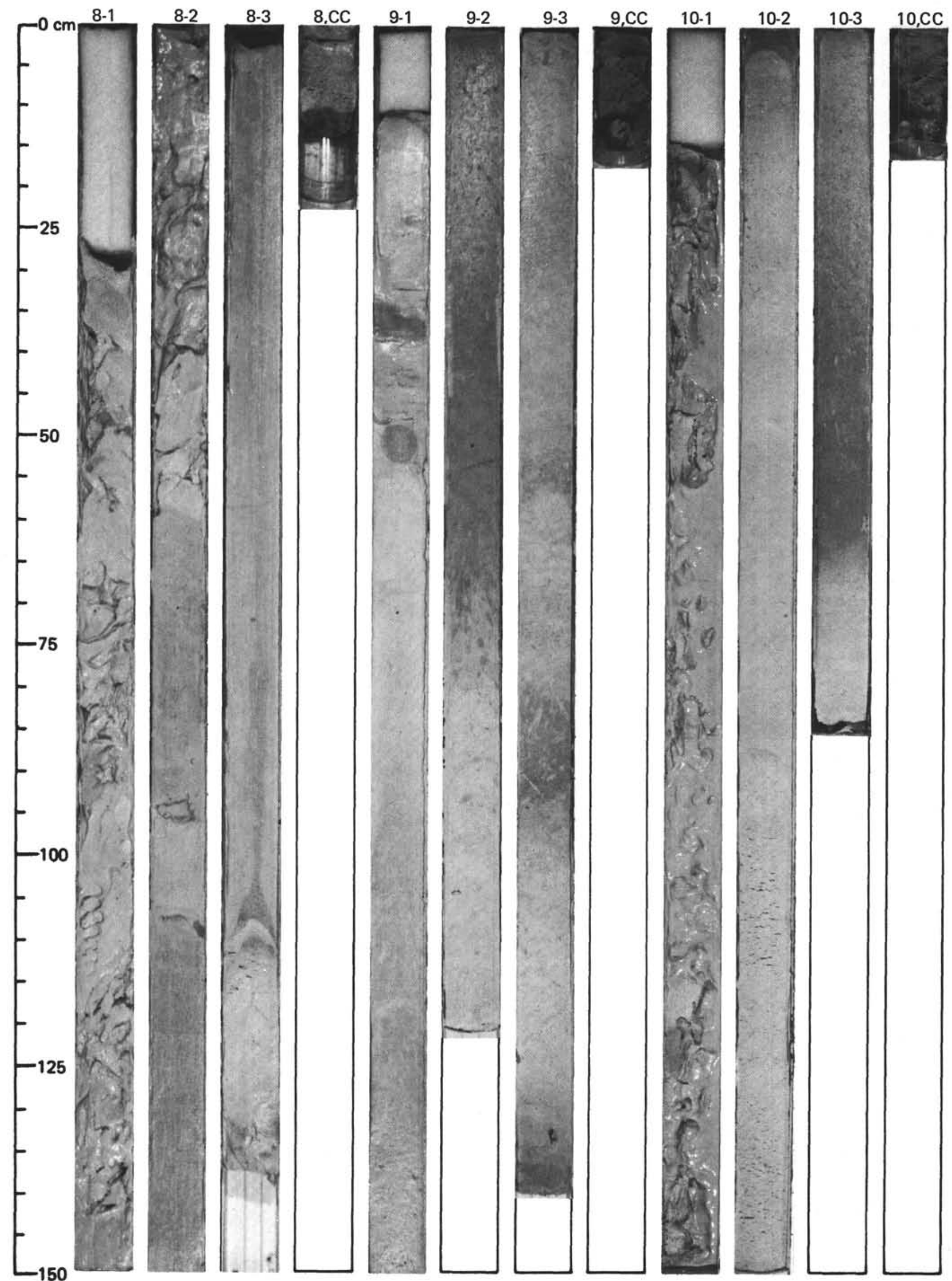


SITE 517 (HOLE 517)

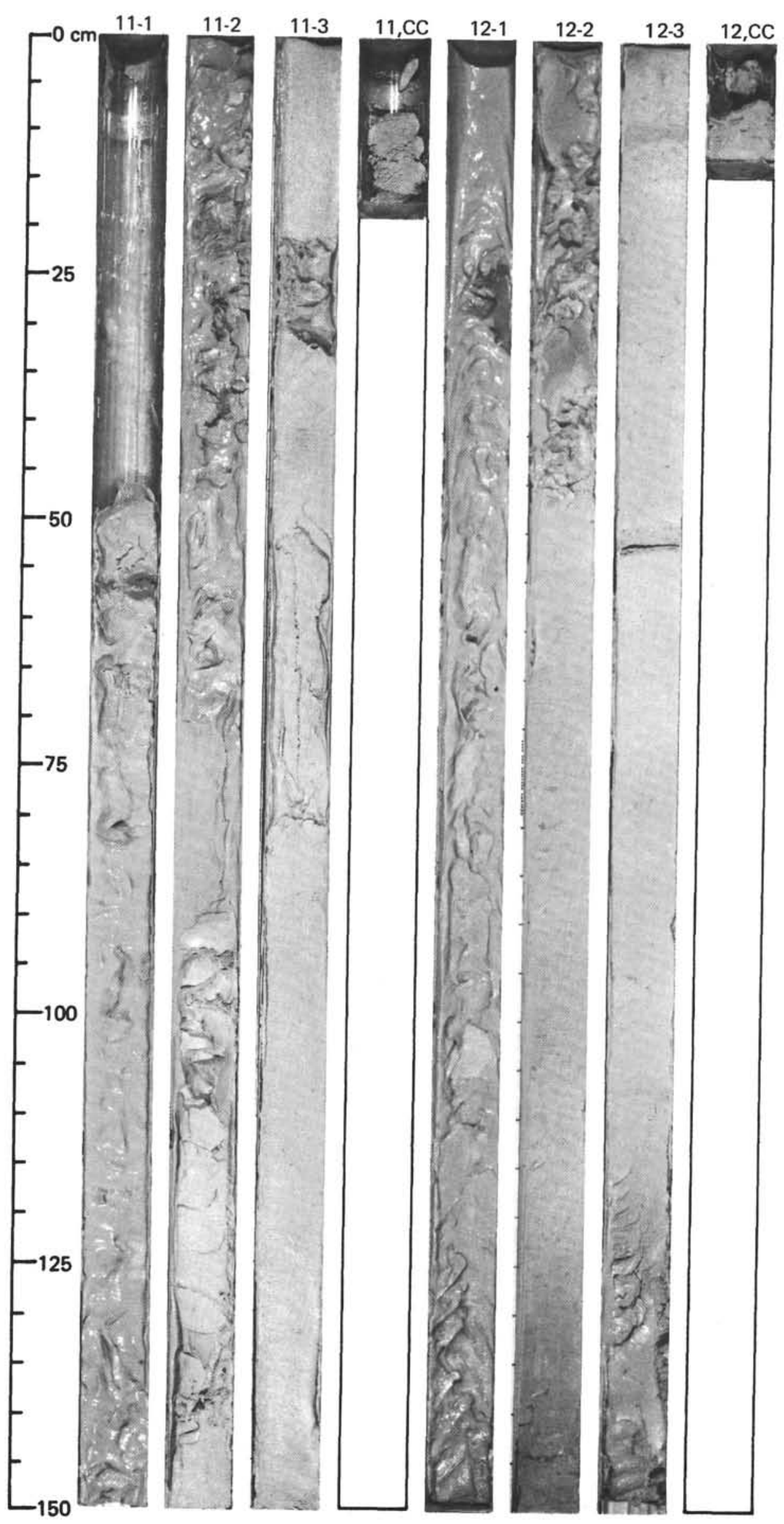

